\title{
Formation of Strategies for the Innovative Development of Industrial Enterprises in a Digital Environment On the Example of PJSC MMK
}

\author{
Tatyana Rakhlis ${ }^{1, *}$ Svetlana Koptyakova ${ }^{1}$ \\ ${ }^{1}$ Nosov Magnitogorsk State Technical University, Russian Federation \\ *Corresponding author.Email: twins08@yandex.ru
}

\begin{abstract}
The article is devoted to the formation of the strategy for the innovative development of industrial enterprises in the digitalisation conditions. The authors raise the problem of innovative development of enterprises in conditions of the fourth industrial revolution, which defines not only the development prospects of large organizations, but also the global market as a whole. The relevance of research into the innovative development of enterprises lies in the fact that the introduction of innovative processes in commercial activity provides opportunities for winning a leading position among the manufacturers of fundamentally new products, creating a highly knowledge-intensive and new product, which will lead to the fact that the products will be competitive in the world market. The aim of the research is to form the strategy of innovative development of PJSC MMK in conditions of technical reequipment and digital economy. The results obtained in the research can be applied in the development of recommendations on the impact of digital technologies on structural changes in the management system of innovative companies, which should be aimed at achieving competitive advantages of industrial enterprises in the Russian and foreign markets of goods and services based on the digital design use of innovative development strategies.
\end{abstract}

Keywords: Industry 4.0, Digitalisation, Digital transformation, Innovation strategies, Industrial enterprise.

\section{INTRODUCTION}

In accordance with the Concept for Long-Term Socioeconomic Development of the Russian Federation until 2030, the transition to an innovative (digital) economy will lead to the changes in the existing employment structure, the employees' redistribution by sectors, the service sector expansion, the development of innovative areas of activity and the emergence of new employment areas. The digital transformation of organisations, both commercial and non-commercial (including state organisations) is a response to the development and active spread of new digital information technologies around the world ${ }^{1}[1$; $10 ; 20 ; 22]$. It should be emphasised that the economy

\footnotetext{
${ }^{1}$ Berger Roland, Industry 4.0: Think Act Point of View. Brussels: Roland Berger.
}

digitalisation level is sufficiently interdependent on its competitiveness today.

PJSC MMK is currently moving towards a digitalisation strategy for the business, which is reflected in the Industry 4.0 project for the integration of all company information flows $[2 ; 9 ; 19]$.

PJSC "MMK" is the Russian metallurgical company operating in accordance with the world requirements of innovative development in the current economic conditions, relying on modern intellectual personnel with high motivation, focused on the development of not only the material and technical base, but also human resources, corporate culture, working conditions and customer requirements.

https://www.rolandberger.com/publications/publication_pdf/roland _berger_tab_industry_4_0_20140403.pdf (2014). 
The main development flagman of scientific and technical policy and innovation activity in PJSC "MMK" is a separate subdivision of the scientific and technical centre, which develops the ideas of top management in the direction of the organization innovation activity as a whole. One of the main activities is the development of new technologies that will enable the production of a new product that is globally competitive and has high added value [12; 14]. Another important task is to change the production technology of the products with reduced production costs [5].

The development of innovation is one of the priorities for PJSC MMK, as in the era of the fourth industrial revolution it is not more and faster production that comes to the fore, but rather the production of new, different products.

In today's economy, the direction of companies' development in the metallurgical industry is changing. PJSC "MMK" finds resources and opportunities for innovative development, which involves not only the innovation process organization, but also the resource base formation and an interaction system with other economic entities. The condition of intensive use of innovative enterprise potential is social and economic adaptation of business structures to peculiarities of life cycle of innovative processes. The basic capital of business will be not so much land, technology and finance, as knowledge and qualification of people. In the course of this study, as a strategy for the innovative development of an industrial enterprise, it is necessary to understand the management process $[7 ; 18]$, the key objective of which is the process of creating and maintaining the long-term stable competitiveness of the innovative enterprise activity according to the current financial situation and the level of innovative possibilities under the influence of the external environment factors [3].

As the authors of the study rightly remark that the strategy of innovative development of an industrial enterprise is of particular importance, designed to reorient its own production towards ever-increasing customer demands, to react more flexibly and further implement timely transformations, and to increase its competitive advantages in the long term [15]. To date, radically new digital technologies and the latest modern business models are being integrated into the existing economic spheres of society, with their direct impact on the economy itself, and other, better-quality transformations are being structured in it. There is therefore no doubt about the timeliness of this work.

\section{RESEARCH METHODS}

Theoretical and methodological basis of the study was formed by the works of foreign and domestic authors devoted to Industry 4.0: management, digital transformation; optimisation of business processes for transition to sustainable development in the context of the Fourth Industrial Revolution, such as: A.L. Lisovsky (2018), A.I. Borovkov, Yu.A. Ryabov, V.M. Maruseva (2018), I.N. Kosareva, V.P. Samarina, (2019), Roland Berger (2014), Schallmo, D., Williams, C.A., Lohse, J. (2019), Rader, D. (2019), etc.

Methods for assessing the economic efficiency of metallurgical industry enterprises are dedicated to the following authors: Mayorova, T.V., Ponomareva, O.S. (2015), N.V. Skvortsova, T.P. Rakhlis, (2017, 2020), Kostina N.N., Koptyakova S.V., Zinovyeva E.G. (2019).

The study was based on the analysis of the effectiveness of strategies for the innovative development of a metallurgical enterprise. We used four methods for assessing the strategy of innovative development: analysis of maximizing innovative projects, analysis of the prospects of innovative projects; analysis of the implementation of innovative projects; diffusion analysis of innovation. These methods are based on taking into account the peculiarities of the development and implementation of new technologies and are aimed at analyzing the maximization of the results of innovative projects, assessing their prospects and feasibility [17]. The considered evaluation system (based on a number of economic criteria) of the innovative strategy of a metallurgical enterprise is presented by the authors in the research results.

This approach will allow an enterprise to realistically assess its innovative resources, according to which it can initially make an adequate choice of further directions for innovative development and thereby avoid investing in economically unrealizable projects.

The research conducted in the article is based on secondary data obtained from many professional reports of the company: financial and economic reports of PJSC "MMK" for 2017-2020; regulatory legal documents; reports of the chief specialists of PJSC "MMK".

\section{RESULTS}

The basis for the innovative company development must necessarily be an innovative strategy, which is created on the basis of a modern management system designed to develop innovative activities, increase 
innovative activity and organise a favourable investment climate. The assessment system of the innovative strategy at the metallurgical enterprise as the initial formation stage of the technological development strategy allows the enterprise to analyse its current investment opportunities in the innovative sphere before the start of scientific and technological search based on a number of economic criteria. Such an approach also allows the company to realistically assess its innovative resources, according to which it can initially make an adequate future direction choice of innovative development and thus avoid investing in economically unfeasible projects $[6 ; 8 ; 21]$.

In other words, objective knowledge of their initial innovative capabilities allows companies to avoid irrational costs associated with generating and selecting innovative development strategies.

The creation of an effective strategic management system for enterprises in the metallurgical industry will also increase the investment attractiveness and fruitfulness of scientific research in the metallurgical industry $[11 ; 16]$. The practical implementation of the innovation development strategy may raise the problem of implementing promising innovation projects. In order to avoid this, it is necessary to closely develop a system of scientific and technical forecasting at enterprises [4]. The solution of these problems determines the urgent need to develop methods and approaches to strategic planning for the innovative development of enterprises in the metallurgical industry, leading to an increase in their innovation activity, achieving long-term competitive advantages and creating the so-called economy of leadership and innovation at the state level. Accordingly, innovation activity is intended to become an integral part of the corporate strategy of modern industrial enterprises, and innovation activity, in its turn, is intended to be their significant competitive advantage.

The analysis of PJSC "MMK" innovation development strategy in the conditions of technological re-equipment and digital economy revealed that one of the key areas of MMK development has become the development of automation and digitalization of all business processes in recent years. In this area, Magnitogorsk is one of the leaders in the domestic metallurgy and Russian industry in general. In 2019, a corporate program to increase operational and functional efficiency was approved, called "Business System Evolution". The main areas of MMK's information strategy are an integrated corporate information system, mobile access to key business applications, modelling and forecasting, end-to-end production planning an order basis and operational order execution management. At the same time, the use of machine vision tools, predictive analytics based on large data, software robotics and artificial intelligence is expected to become increasingly active. The implementation of digital initiatives will allow MMK to increase the overall efficiency of all business processes, reduce the consumption of material, technical and energy resources, increase the speed of decision-making and significantly reduce costs.

PJSC MMK's strategic goal remains unchanged for the period until 2025. The company aims to become a leader among the world's steel companies with comparable production volumes by total shareholder return. In order to achieve this goal, PJSC "MMK" works in a number of key priority areas through specially developed strategic initiatives.

In 2020 PJSC "MMK" approved a new strategy for the development of information technologies, which was developed by PJSC "Magnitogorsk Iron and Steel Works" together with LLC "Deloitte Consulting" and covers the period until 2025.

The need to update the IT strategy arose after the adoption of a new digitalisation strategy for the company in 2019, since all MMK digitalisation projects without exception contain IT components.

PJSC MMK's IT-2025 strategy includes the implementation of 27 strategic initiatives, among them: unification of platforms and solutions for basic automation; application of cloud solutions for relevant classes of systems; unification of MES-systems platform for production automation; support and development of IT infrastructure in accordance with the growing requirements of IT solutions and business users; increase of disaster tolerance of IT infrastructure; development of information security tools; regular updating of needs and coordination with the Digital Office to support the implementation of MMK's digitalisation strategy; adaptation of the management operating model to the needs of business users; and adaptation of MMK's digitalisation strategy.

The results of the coefficients analysis of the enterprise innovation and innovation-investment activity, which testify to the introduction and implementation of the innovation development strategy in PJSC "MMK" are presented in Table 1. The calculations are clearly shown in Figure 1. 
Table 1. Analysis of innovation and innovation-investment activity ratios of the company

\begin{tabular}{|c|c|c|c|c|c|c|}
\hline \multirow{2}{*}{ Characteristics } & \multirow{2}{*}{ Base units } & \multicolumn{3}{|c|}{ Calculation data } & \multirow{2}{*}{ Conclusions } & \multirow{2}{*}{ Strategy choice } \\
\hline & & 2017 & 2018 & 2019 & & \\
\hline $\begin{array}{l}\text { Intellectual Property } \\
\text { Security Ratio - } \\
\text { determines whether a } \\
\text { company has intellectual } \\
\text { property (Cip). }\end{array}$ & $\begin{array}{l}\text { Cip }>0.10 \ldots . .15 \\
\text { mastering of } \\
\text { basic } \\
\text { innovations } \\
\text { Cip<0.10...0.15 } \\
\text { mastering of } \\
\text { improving } \\
\text { innovations }\end{array}$ & 0,0063 & 0,0085 & 0,0001 & $\begin{array}{l}\text { The Company } \\
\text { does not pay } \\
\text { attention to } \\
\text { intellectual } \\
\text { property objects. }\end{array}$ & $\begin{array}{l}\text { Consistent } \\
\text { strategy }\end{array}$ \\
\hline $\begin{array}{l}\text { Ratio of personnel } \\
\text { employed at RI and R\&D } \\
\text { - shows the share of } \\
\text { personnel directly } \\
\text { involved in the } \\
\text { development of new } \\
\text { technologies (Cpd) }\end{array}$ & $\begin{array}{l}\text { Cpd }<0.20 \ldots 0.2 \\
5 \text { - adoption of } \\
\text { improvement } \\
\text { technologies }\end{array}$ & 0,18 & 0,23 & 0,21 & $\begin{array}{l}\text { Insufficient share } \\
\text { of personnel } \\
\text { employed in } \\
\text { R\&D }\end{array}$ & $\begin{array}{l}\text { Consistent } \\
\text { strategy }\end{array}$ \\
\hline $\begin{array}{l}\text { Ratio of assets held for } \\
\text { R\&D - shows the share of } \\
\text { assets held for R\&D (Car) }\end{array}$ & $\begin{array}{l}\text { Car }<0.20 \ldots 0.25 \\
\text {-improving } \\
\text { technologies } \\
\text { development }\end{array}$ & 0,09 & 0,14 & 0,17 & $\begin{array}{l}\text { Low share of } \\
\text { research } \\
\text { property }\end{array}$ & $\begin{array}{l}\text { Consistent } \\
\text { strategy }\end{array}$ \\
\hline $\begin{array}{l}\text { New Technique Ratio - } \\
\text { describes the ability of } \\
\text { the enterprise to master } \\
\text { new equipment (Cme) }\end{array}$ & $\begin{array}{l}\text { Cme }>0,20 \ldots 0,2 \\
5 \text {-mastering } \\
\text { basic } \\
\text { innovations }\end{array}$ & 0,53 & 0,35 & 0,47 & $\begin{array}{l}\text { The company is } \\
\text { able to master } \\
\text { new equipment }\end{array}$ & $\begin{array}{l}\text { Leader's } \\
\text { strategy }\end{array}$ \\
\hline $\begin{array}{l}\text { New Product Rate - } \\
\text { describes the ability to } \\
\text { introduce new products } \\
\text { (Cip) }\end{array}$ & Cip $>0,20 \ldots 0,25$ & 0,41 & 0,54 & 0,55 & $\begin{array}{l}\text { The Company is } \\
\text { able to } \\
\text { introduce new } \\
\text { products }\end{array}$ & $\begin{array}{l}\text { Leader's } \\
\text { strategy }\end{array}$ \\
\hline $\begin{array}{l}\text { Innovation Growth Ratio } \\
\text { - characterizes the } \\
\text { sustainability of } \\
\text { innovation growth (Cig) }\end{array}$ & Cig $<0,20 \ldots 0,25$ & 0,01 & 0,012 & 0,03 & $\begin{array}{l}\text { Innovative } \\
\text { company } \\
\text { growth is not } \\
\text { sustainable }\end{array}$ & $\begin{array}{l}\text { Follower's } \\
\text { strategy }\end{array}$ \\
\hline
\end{tabular}

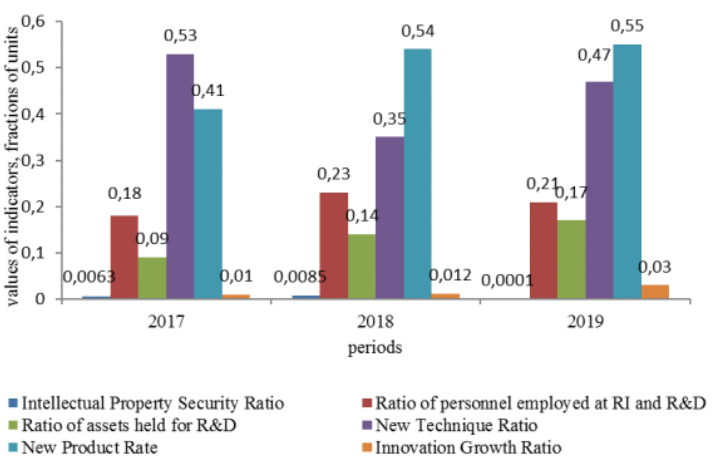

Figure 1 Analysis of innovation and innovationinvestment activity ratios of the company
The results obtained in the course of the innovation project evaluation make it possible to select the most promising technology to be introduced into production, find ways to reduce investment costs and increase the economic attractiveness and efficiency of innovations.

They can also serve as a substantive basis for presenting innovation development strategies in the form of traditional business plans or innovation and investment projects.

Positive aspects of the activities of PJSC "MMK", of a large metallurgical enterprise, are positive: 
- the enterprise is capable of mastering new machinery and innovative equipment under conditions of technological re-equipment and digital economy;

- increase in the volume of production activity in the domestic and foreign markets;

- increase in the company's profit through profitable innovation projects of various nature, taking into account the digital economy.

\section{CONCLUSION}

Thus, taking into account theoretical and practical research, it can be said that the approach under consideration allows the company to realistically assess its innovative resources, according to which it can initially make an adequate choice of the future direction of innovative development and thus avoid investing in economically unfeasible projects. In other words, objective knowledge of their initial innovative capabilities allows companies to avoid irrational costs associated with the generation and selection of innovative development strategies. The practical implementation of an innovation development strategy may raise the problem of implementing promising innovation projects. However, the results obtained in the course of conducting an innovation project assessment make it possible to select the most promising technology to be introduced into production, find ways to reduce investment costs and increase the economic attractiveness and efficiency of innovations. They can also serve as a substantive basis for presenting innovation development strategies in the form of traditional business plans or innovation projects.

If we sum up the selected strategy of PJSC "MMK", it can be attributed to the strategy of the follower, the positive points of which are: the company is able to master new equipment and innovative equipment in the conditions of technological re-equipment and digital economy; increase the volume of production activities in the domestic and foreign markets; increase profits through profitable innovation projects of various nature, taking into account the digital economy. Implementation of the strategy will allow PJSC "MMK" to achieve the required target state of information technologies, which will meet the needs of business and the requirements of the time.

\section{REFERENCES}

[1] Alp Ustundag, Emre Cevikcan. Industry 4.0: Managing. The Digital Transformation. Springer. 2017, 293 p.
[2] A.I. Borovkov, Yu.A. Ryabov, V.M. Maruseva, A new paradigm for digital design and modeling of globally competitive next generation products. Digital production: methods, ecosystems, technologies 2018, pp. 24-44.

[3] A.I. Borovkov A.A., Gamzikova, K.V. Kukushkin, Yu.A Ryabov Digital twins in the high-tech industry, in: Brief report - SPb.: POLITECHPRESS, 2019, $62 \mathrm{p}$.

[4] E. Balashova, I. Krasovskaya, E. Schislyaeva, F. Shamrai, Calculation and analytical instrumentarium for estimating the economic efficiency of the digital technologies development process, IOP Conference Series: Materials Science and Engineering 497 (1) (2019) 012107, DOI: $10.1088 / 1757-$ 899X/497/1/012107.

[5] P.N. Bilenko, L.V. Lysenko, S.L. Lysenko, I.S. Zavaleev, Comprehensive assessment of enterprise development as a tool for increasing labor productivity - M., Skolkovo, Digital manufacturing. Methods, ecosystems, technologies. Working paper of the Corporate Education Department of the Moscow School of Management SKOLKOVO. http://odm3.io/

[6] M.K. Chernyakov, M.M. Chernyakova, K.Ch. Akberov, Dynamic model of social risks in the digital economy. Proceedings of the 1-st International Scientific Conference «Modern Management Trends and the Digital Economy: from Regional Development to Global Economic Growth», $81 \quad$ (2019) 371-376. DOI:10.2991/mtde-19.2019.71

[7] E.V. Danilyuk, S.V Koptyakova, Strategies for innovative development of personnel management in modern economic conditions. Scientific thought: tradition and innovation. Sat. scientific. tr. I All-Russian Scientific and Practical Conference, 2020, pp. 299-303.

[8] N.N. Kostina, S.V. Koptyakova, E.G. Zinovyeva, Fuzzy sets theory as the method for managing integration risks at iron and steel works. Memedzhment v Rossii i za rubezhom 3 (2019) 48-58.

[9] I.N. Kosareva, V.P. Samarina, The management features of the enterprises in the conditions of digitalization, The Eurasian Scientific Journal 3(11) (2019).

[10] A.L. Lisovsky, Optimization of business processes for transition to sustainable development in the conditions of the fourth 
industrial revolution. Strategic decisions and risk management (4) (2018) 10-19. DOI:10.17747/2078-8886-2018-4-10-19

[11] T.V. Mayorova, O.S. Ponomareva, Methodology for assessing the economic efficiency of environmental management of enterprises in the metallurgical industry. Bulletin of Nosov Magnitogorsk State Technical University, 2015, pp. 112-116.

[12] Yu.V. Polyanskov, A.S. Kondratyeva, M.S. Chernikov, A.A. Blyumenshteyn, Integration of CAPP, PDM, ERP systems in the common information space of manufacturing enterprise. Bulletin of the Samara Scientific Center of the Russian Academy of Sciences 15-4 (3) (2013) 628-633.

[14] Rader, D., Digital maturity - the new competitive goal, in: Strategy and Leadership 47 (5) (2019) 28-35. DOI: 10.1108/SL-06-2019-0084

[15] Z. Satskaya, Keeping up with the times or staying ahead of the curve? Additive technologies, (29) (2018) 22-23.

[16] N.V Skvortsova, T.P. Rakhlis, Tools for improving the efficiency of management decisions when attracting debt capital by industrial enterprises. Economics and Entrepreneurship 11 (88) (2017) 1000-1006.

[17] N.V. Skvortsova, T.P. Rakhlis, I.A Savelyeva. Economic Assessment of the Effectiveness of the Introduction of Industry 4.0 Technologies in the Activities of Industrial Enterprises. Advances in Economics, Business and Management Research 156 (2020) 474-479.

[18] D. Schallmo, C.A. Williams, J. Lohse, Digital strategy - Integrated approach and generic options, in: International Journal of Innovation Management $23 \quad$ (8) (2019) DOI: $10.1142 / \mathrm{S} 136391961940005 \mathrm{X}$

[19] M.Yu. Volshchukov, V.Yu Rybolovlev., Yu.N Volshchukov,. P.L. Makashov, From integration to convergence in enterprise automation: practical aspects of digitalization of the Russian economy, Corporate Economics 3(19) (2019) 412.

[20] G. Vial, Understanding digital transformation: A review and a research agenda, in: Journal of Strategic Information Systems 28 (2) (2019) 118144. DOI: $10.1016 /$ j.jsis.2019.01.003

[21] E.G. Zinovieva, S.V. Koptyakova, Assessment of integration risks for metallurgical enterprises using the fuzzy set method, CIS Iron and Steel Review 17 (2019) 58-64. DOI: 10.17580/cisisr. 2019.01.11

[22] A. Zangiacomi,. E. Pessot, R. Fornasiero, M. Bertetti, M. Sacco, Moving towards digitalization: a multiple case study in manufacturing, in: Production Planning and Control 31 (2-3) (2020) 143-157. DOI: $10.1080 / 09537287.2019 .1631468$ 